\title{
THE POSSIBLE EFFECTS OF VARIOUS OTOTOXIC DRUGS \\ UPON THE ATP-HYDROLYZING SYSTEM IN THE STRIA \\ VASCULARIS AND SPIRAL LIGAMENT OF THE \\ GUINEA PIGS
}

By

Toshitaka IINUMA, M.D.

From the Department of Otorhinolaryngology, Tokyo University, School of Medicine, Bunkyo-ku, Tokyo, Japan. (Director. Prof. Ichiro Kirikae)

The present report is concerned with the possible effects of various ototoxic drugs upon the enzymatic ATP-hydrolyzing system in the stria vascularis and spiral ligament of the guinea pigs which were intoxicated with these drugs by parenteral administration. The membrane ATPase, which is said to be closely related with the active transport of both sodium and potassium across the biological membranes, showed a decrease in com. parison to the normal cases, whereas the ouabain. insensitive componenent showed an increase. The ATP-hydrolyzing system as a whole did not yield any common results.

The vestibular portion of the membranous labyrinth showed rather bizzare picture, so that no generalization of the changes was possible.

\section{耳中毒性薬物のモルモツト血管条および螺旋靱帯の $\mathrm{ATP}$ 水解系に対する影響について}

東京大学医学部耳與咽喉科学教室，大学院学生（主任 切替一郎教授）

飯渠奉孝

目次

1. 绪馀

2, 万法

1) 動物潐備法

2) 組蟣粱備法

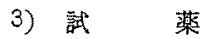

4) 酵案活性度湘定法

5) 乾燥重量测定法

3. 龆 果

1) 正常動物に拈ける醉替活性分布

2) カナマイシン中毒例の醅素活性分柯

3）ストレプトマイシン中毒例の醉装活性分布

4) デハイドロストレプトマイシン中毒例の酵䋕活 性分布

5)結果のまとめ

4. 㛟討
1）耳中毒性楽物の体內分布について

2）耳中毒性薬物の作用機序について

3） ATP 水解系への影響について

5)まとめ

\section{1. 緒論}

1944 年 Wachsman がストレプトマイシンを発見し て以来，化学治療法の分野に战いて大きな進歩がもたら され，感染症，特に結核の治療法は躍進的変化をとげ た.

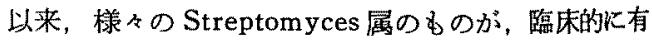
効な杭生物質を逢することがわかり，デハイドロストレ プトマイシン，カナマイシンなどがその群に加かつた。 間もなくこれらの薬物は副作用むあることが判明した。 我々の分野で注目されたのは耳中毒性である。この問 題に関しては多くの出版がなされ，基礎部門，隔床部門 に扣いて充分の検討が進んだ，Berg (1)，Lindsay 他 


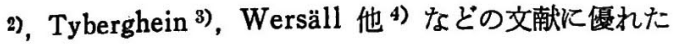
概論が見出される。

耳中毒性薬物汇関する研究の大部分は主に 感覚上皮 系, 即ち, コルチ氏器管および前庭上皮系に関するもの であるが，膜迷路のその他の部分に関するものも存在す る.

血管条仙和りる種々な退行変化孔数多くの文献に報告 された (Rüedi ${ }^{5)}$ ， Riskaer 他 ${ }^{6)}$, 中村 7), Lindsay 他 2)).

これより先 $\left(\right.$ 飯难 ${ }^{8)}$.) 正常モルモットの血管条と螺 旋刎帯の Adenosine Triphosphatase (ATPase) につ き詳細な報告がなされた。

今回の報告は耳中毒性薬物が ATP 水解系に及活し 得る変化についてなされる。

\section{2. 方法}

1) 動物準備法

正常耳介反射を有する大人モルモットを使用した．耳 中毒性薬物は，ストレプトマイシン，デハイドロストレ プトマイシン，カナマイシンであつて，腹腔内注射法が とられた．以上の楽物の Sulfates が $400 \mathrm{mg} / \mathrm{kg}$ で毎 日注射された（但し土曜，日隐を除く）。20日間をもつ て注射期間とした. 各楽物につき 20 匹が使用された。

注射期間中，約 15\%の 動物が死亡した． 注射終了後 、日以内に動物は使用された。

2) 組織準備法

前出. (飯沼 ${ }^{8)}$ ) 参照.

3) 試薬

カナマイシン (有効量 770micrograms/mg) は Bristol Laboratories より供給された. ストレプトマイシ ン（有効量 700 micrograms/mg 以上), デハイドロス トレプトマイシン（有効量 $740 \mathrm{micrograms} / \mathrm{mg}$ 以上） は Nutritional Biochemicals Corp. 上り購入された. ATPは Sigma Chemical Co. より購入された. Ouabain は Mann Research Laboratories より購入され た. 他の共通試薬は Reagent Grade で，すべてガラ ス再蒸溜水をもつて淮備された。

4）酵素活性度測定法

詳しくは文献 (飯沼 $\left.{ }^{8)}\right)$ 参照. ATP より酵素的遊離 を受けた無機りン酸は Fiske-Subba Row 法 (Fiske 他 9)）の变法により測定された。

5) 乾燥重量測定法

詳し〈は文献 ${ }^{8)}$ 参照. Helix, Quartz Balance (Microchemical Specialities Co.) が用いられた。
3. 結 果

1）正常動物に特ける䤃素活性分布

図一1 飞は酵素的 ATP 水解系の種々な成分の膜迷路 に淤ける分布が示してある.

図 1 正常モルモツト膜迷路に和ける

活 性 度 分布

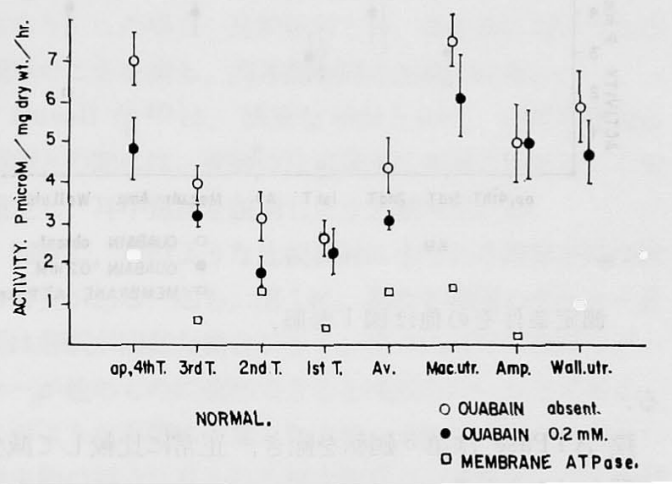

Temp. $37^{\circ} \mathrm{C}$. pH7.5, Na $25 \mathrm{mM} . \mathrm{K} 140 \mathrm{mM}$. $\mathrm{Mg} 2.5 \mathrm{mM}$. Tris $20 \mathrm{mM}$. ATP $2.5 \mathrm{mM}$.

縦線は標準偏差を示す，各点は侧頭骨12簀の測 定值の平均を示す

Ap. は Apex, 4th T. 第 4 迴転, 3rd T. は 第 3 趈枟, 2nd T. は第 2 趈転, 1st T. は第 1 趈転, Av. は lst T. を除く. 以上の平均値で ある。

Mac. utr. は Macula utriculi, Amp. は Ampulla semicanalis, Wall utr. は Utriculusの壁を各々指す。

ATP 水解系全体としての活性度は第 1 回転から Apex に行くに従つて高くなる.このことは Ouabain で影響を受けぬ成分についてもいえる。膜 ATPase に 関しては，第 3 廻転の活性度が低いため，廻転に従つて の活性度分布は明らかではないこの第3 迴転の活性度 に関して今の所，何の説明もつかない，前庭系膜迷路の 活性も参照まで図示されてある，螖牛系と異なつて，種 々雑多な組織を゙含むものであるため，両者の比較は制限 を受ける。

2）カナマイシン中毒例の活性分布

図一2 はカナマイシン慢性中毒例である. ATP 水解 系全体としてはやはり第1 迴転から Apex に活性度が たかまる傾向をみるが，正常の值に対して一般に活性度 は增加傾向を示す．このことは Ouabain に影響され ない成分についても，第 3 廻転を除き，い方ることであ 
图 2 カナマイシン慢性中毒モルモットの 膜迷路に扮ける活性度分布

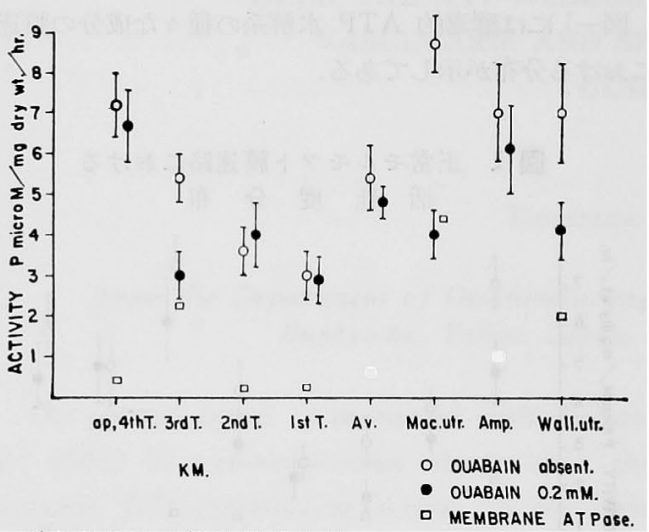

測定条件その他は図 1 参照.

る.

膜 ATPase は第 3 廻転を除き，正常に比較して減少 の傾向がみられる.

前庭采膜迷路では, ATP 水解系全体としての活性度 および膜 ATPase は增加傾向を示すに反し，Ouabain で影響されない部分は正常に比較して減少傾向を示す.

3）ストレプトマイシン中毒例の活性分布

図一3はストレプトマイシン慢性中毒例の 活性度分布 を示す. ATP 水解系全体としての活性度及び Ouabain に影響されない成分の活性度は，第 1 迴転から Apex の順に增加を示すのは正常のものと同じである．また， 活性度は正常よりは增加の傾向を示す 膜 ATPase は 第3 迴転を除き，正常値に比較して減少傾向を示す．

図 3 ストレプトマイシン慢性中毒モルモットの 膜迷路に拈ける治性度分布

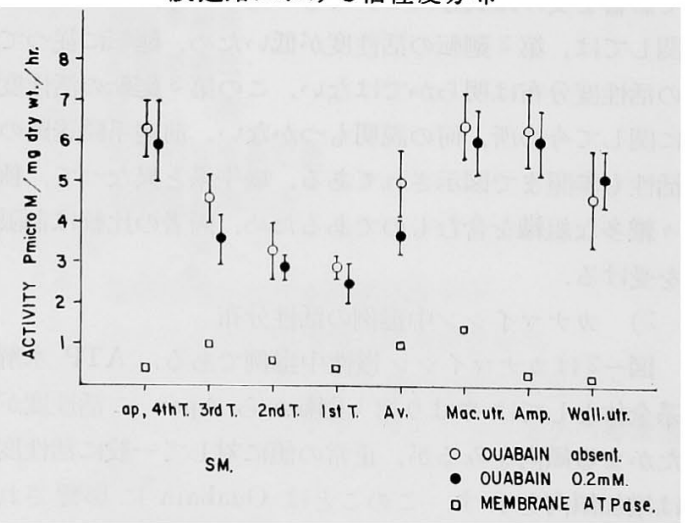

測定条件，その他は図 1 参照.
前庭系膜迷路は変化が雑多であつて，一般的㑯向は示 し難い。

4）デハイドロストレプトマイシン中毒例の活性分布

図一4 はデハイドロストレプトマイシン慢性中毒例の 活性度分布を示す．ATP 水解系全体および Ouabain で影響を受けぬ成分の 活性度が第 1 迴転から Apex の 順に增加をするのは正常例と同じである，但し，ATP 水解系全体と膜 ATPase の活性度は正常例に比較して, 減少傾向を示す.

図 4 デハイドロストレプトマイシン慢性中毒 モルモツトの膜迷路における活性度分布

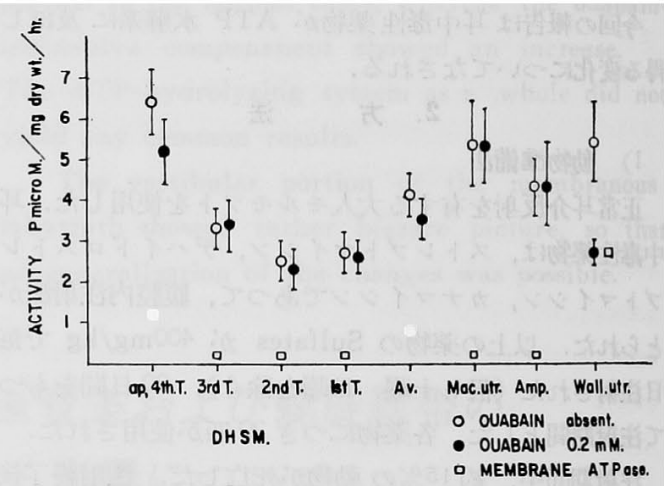

測定条件，その他は図1参照。

Ouabain で影響を受けぬ成分は増加傾向を示す． 前 庭系膜迷路では，すべての成分が減少傾向を示す. 但し Utriculus の壁は除く。

5) 結果のまとめ

表一1 は今回の報告の一覧表である、

血管条と螺旋靱帯に拈いては，ATP 水解系全体とし ての活性度は, カナマイシンとストレプトマイシンの場 合に正常に比して増加の傾向を示すが, デハイドロスト レプトマイシンでは減少の傾向がある，Ouabain に影 響されない成分の活性度は共通して增加傾向を示す．膜 ATPase は共通して 娍少傾向を示す，前庭系膜迷路て は Ouabain に影響を受けぬ成分のみが共通して減少傾 向を示すが，他の成分は結果が雑多で一般論が不可能で ある。

\section{4. 検 討}

1）耳中毒性薬物の体内分布について

ストレプトマイシン，デハイドロストレプトマイシ ン，カナマイシンの体内分布，吸収和よび排池は大体に 
表 1 耳中慗性莱物の影響のまとめ

\begin{tabular}{|c|c|c|c|c|c|c|c|c|}
\hline & $\begin{array}{l}\text { ap. } \\
4 \text { th } \mathrm{T}\end{array}$ & $\begin{array}{l}3 \mathrm{rd} \\
\mathrm{T}\end{array}$ & 2nd & $\stackrel{1 \text { st }}{\mathrm{T}}$ & Av. & Mac. & Amp. & $\begin{array}{l}\text { Wall- } \\
\text { utr }\end{array}$ \\
\hline 1 & 0 & $+t$ & + & $t$ & ++ & $+t$ & $t+$ & + \\
\hline $\mathrm{KM} 2$ & $+t$ & - & ++ & ++ & ++ & -- & 0 & -- \\
\hline 3 & -- & $+t$ & -- & - & -- & $+t$ & ++ & $+t$ \\
\hline 1 & -- & $+t$ & 0 & 0 & ++ & -- & + & -- \\
\hline $\mathrm{SM}^{2}$ & $+t$ & + & $t+$ & 0 & $+t$ & -- & 0 & $+t$ \\
\hline 3 & -- & + & -- & 0 & - & 0 & + & -- \\
\hline 1 & - & -- & -- & -- & - & -- & -- & $+t$ \\
\hline $\begin{array}{l}\mathrm{H} \\
\mathrm{S}\end{array}$ & + & 0 & $+t$ & + & 0 & -- & - & - \\
\hline$M \quad 3$ & -- & -- & --1 & -- & -- & -- & -- & ++ \\
\hline \multirow{4}{*}{\multicolumn{9}{|c|}{$\begin{array}{l}\text { 1. Total ATP-hydrolysis } \\
\text { 2. OUABAIN insensitive comp. } \\
\text { 3. OUABAIN sensitive comp.= } \\
\text { Membrane ATPase }\end{array}$}} \\
\hline & & & & & & & & \\
\hline & & & & & & & & \\
\hline & & & & & & & & \\
\hline $\begin{array}{r}++: \\
+:\end{array}$ & \multicolumn{8}{|c|}{$\begin{array}{l}\text { 正常值に対して } 0.5 \text { 以上の活性度の增加. } \\
0.2-0.5 \text { の間の活性度增加. }\end{array}$} \\
\hline $0:$ & \multicolumn{8}{|c|}{ 正常値との差の絶対值が 0.2 より少い。 } \\
\hline$一$ : & \multicolumn{8}{|c|}{ 0.2-0.5の間の活性度減少. } \\
\hline -: & \multicolumn{8}{|c|}{0.5 以上の活性度減少. } \\
\hline
\end{tabular}

执いて同しであるとい5 (Buggs 他 ${ }^{10)}$, Marshall1), Levin, 他 ${ }^{12)}$, Rake 他 ${ }^{13)}$, Cronk, 他 ${ }^{14)}$ )。 ストレプ トマイシンの場合には，体積分布がほぼ全体の30\%であ つて，これは細胞外液に分布することを思わせる(Mar－ shall (1)).

ストレプトマイシンは，また，細胞壁内には入らない Robson, 他 ${ }^{15)}$ ). ストレプトマイシン,デハイドロストレ プトマイシンはともに脳䨐髄液には移行がわるい（Levin 他 ${ }^{12)}$ ).カナマイシンの移行は相当量みられる(Tisch 他 ${ }^{16)}$ ).

選択的耳中毒性の説明の試みとして，内リンパ夜には 漂縮された状態でこれらの薬物が分布されるのではない かといら想像がある (Wersäll 他 ${ }^{4}$ ， Duvall，他 $\left.{ }^{17}\right)$.

但し，内耳液内に和けるこれら薬物の濃度を直接儿測定 した研究によれば (Voldrich $\left.{ }^{18)}\right)$ ，蒋物の移行は極めて

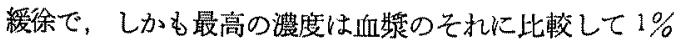
見当であるという，これらの事奉から，澧度ではなく で，薬物の排出速度がむしろ耳中毒性に関連するのでは ないかという，一方，Stupp 他 ${ }^{29}$ によ饥ば，カナマイ シンは内耳液において血中濃度より相当に高濃度に存在 するといら、いずれにして子内耳液に执いては，他の細
胞外液とは異なる分布を考えるのが，濃度説，接触時間 説に共通する見方であるようである。それならば何故に 膜迷路のさしろ特定した筒所が侵されるかに関しては説 明がない。

2) 耳中毒性薬物の作用機序について

·抗生物質の作用機序を比較検討することにより，若し 耳中毒性の問題が解明され得るとしたら，非常に有益で あろう。この場合，比較検討とは，微生物に対する作用 機序のことを指し，高等動物間の比較ではない，

Duvall 他 ${ }^{17)}$ は，慎重な検討と共に，内耳の細胞と 細菌との間には，薬物の作用機序に共通点があることを 想定し，耳中堽性を説明しょうと試みている。

同時に，このような比較検討にまつわる困難さには次 の事実がある、即ら，第 1 に，異なる種属のデーター分 析は解秎が困難な場合が多く，第 2 に異なる種属のデー ターが他のるのに適応できるとは限らないからである。 このよらな事情に留意した上で, 主に生化学の見地から 微生物の場合に見られる抗生物質の作用機序につき概略 をのべる。

ストレプトマイシンは他のすのに比べて広範用に研究 されて，データーも豊富であるので，主にストレプトマ イシンにつきのベる事になる，他のデハイドロストレプ トマイシンやカナマイシンの作用機序も，完全な証明や データーは欠くが，多分同じであるうといわれる（Feingold ${ }^{19)}$ ).

他の多くの抗生物質の場合にみられるごとく、ストレ プトマインンもまた, 活動的に分割を続けている微生物 に最守效果が強く，休止期のbのには比較的作用が弱 い(Robson 他 ${ }^{15)}$ ). ストレプトマイシンは，多くの研 究がなされたのにもかかわらず，種々の型式の作用機序 が仮定され，現在にいたるまで，主な作用，殊に感受性 のある微生物への抑制が何であるか解つていないといら (Gale ${ }^{20)}$ ). 一般的に，ストレプトマインンの作用機序 は細胞膜（但し，これは硬い細胞壁の内㑡の柔い細胞膜 (Plasma Membrane) を指す) に対するものと，蛋白 命成に対するるのとに分けられるようである，大腸菌な どの場合，カリウムの流出增加が最も初期の生化学的变 化であるといち (Dubin, 他 ${ }^{21)}$ )。

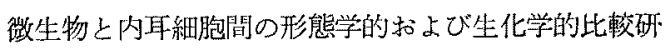
垫については，殆えど知られていないため，少くとも現 在の㭙点では，微生物の硚究から得た結果を類似的に内 耳にもたらすのは，余りにも仮定の段階が多すぎるすの と思加扎る。 
3） ATP 水解系への影響について

ATPase の局在に開する 組織化学染色法によれば， 形質膜がその部位であつて，しかも能動輸送の活潑な 部位，例えば腸粘膜上皮の Microvilli，筒糸球体の 上皮細胞などに発見されるという(Ashworth，他 ${ }^{22) ， ~}$ Spater 他 ${ }^{23)}$, McClurkin ${ }^{24)}$ ). モルモツトの俱管条 の電子影微鏡的所見によれば，中井26)は Endoplasmic reticulum $K$ ATPase を認めた. 但 L ATPase は Cristae mitochondrialis にも認めら扎る (Ashworth (4也 22)).

今回の報告では，抯管条および螺旋熯带の単一迴転が ATPase の活性度测定にまるごと朋いてある。この組 織片は均一ではなく，これをるつて ATPase の局在は 云々できない，但し前回の報告（飯沼 ${ }^{8) ） に よ れ は ゙ ， ミ ~}$ トコンドリアより由来する ATPase 活性を抑制する濃 度の Oligomycinは, 現在の測定条件下では ATPase に影響がみられなつた。このことから，現在用いてある 組䅧片から测定された ATPase の活性庭は，恐らくミ トコンドリア以外の組胞成分以斗来すると思和れ，先 の電子顕徽鏡所見を考慮に入れるとき，恐らく主に細胞 の膜成分に由来するものと思われる。

今回の耳中毒性薬物を用いての慢性中毒失験では，正 常のモルモツトに比皎して，ATP 水解系に変化が諗め られた。

Ouabain を用いての亚で ATP 水解秀は種々な成 分に分割できるが，そのなかには機能のかかつたものも 解らないものあある。

膜 ATPase は坐物学的膜を通しての力リウムとナ トリウムの能動輸送に临接な関道があるといわれてきた (Judah, 他 ${ }^{26)}$, Whittam ${ }^{27}$ ), Skou 28))。耳印毒性蕌物 の慢性然呀の結果によれば，膜 ATPase の活性は，血 管条と螺旋勒紫において，正常の例に比較して減少して いる.しかし今回の鿬究からは，これが内耳に限定した 变化か全身的なのか恄論できない。

\section{3. ま め}

今回の報告は，種々な耳中毒性桨物の慢性中毒に際

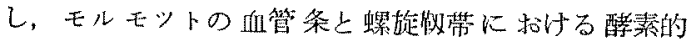
ATP 水解系の变化を㓋察した。

生物学的膜を通してカりウム必よびナトリウムの能動 輸送に密接な関係を有するといわ机る膜 ATPase は正 常に此し減少㑯向を示した，その機能が明らかでない Ouabain に影響されない成分は增加傾向を示した。

ATP 水解系金休上しては，一般的傾问山䫖教ではな bつt:
前庭系膜迷路は，楽物により变化が様々で観察結果火 共通な傾向は見出せなかつた。

\section{文 献}

1) Berg.: The ototoxic effect of streptomycin on the vestibular and cochlear apparatus. Acta otolaryng., Supp., 172, 1951.

2) Lindsay, et al: Histopathologic inner ear changes in deafness due to neomycin. Laryngoscope, 70; 382, 1960.

Tyberghein: Influence of streptomyces antibiotics on the cochlear microphonics in the guinea pig. Acta otolaryng., Supp., 171, $1962 . \quad$ 4) Wersäll et al: The vestibular sensory epithelia in the cat labyrinth and their reactions in chronic streptomycin intoxication. Acta otolaryng., 54; 1962, 5) Rüedi: Some animal experimental findings on the function of the inner ear. Ann. Otol., 60; 993, 1951. 6) Riskaer et al.: The ototoxocity of neomycin. Acta otolaryng., 46; 137, 1956. 7) Nakamura:

Elecctrophysiolgical and cytochemical study of the ototoxicity of dihydrostreptomycin. Ann. Otol., 66; 1080, 1957. 8) Iinuma: Evaluation of adenosine triphosphatase activity in the stria vascularis and spiral ligament of the normal guinea pig. 日耳橆, $69: 9867 \sim 875,1966.99)$ Fiske et al.: The colorimetric determination of phosphorus. J. Biol. Chem., 66; 375, 1925. 10) Buggs et al.; The absorption, distribution and excretion of streptomycin in man. J. Clin. Inv., 25; 94, 1946. 11) Marshall: The absorption, distribution and excretion of streptomycin. J. Pharmacol. Exp. Ther., 92 ; 43, 1948. 12) Levin et al.: The distribution of dihydrostreptomycin in various body fluids. Amer. Rev. Tuberc., 58; 531, 1948. 13) Rake et al.: Further studies on the dihydrostreptomycin. Amer. Rev. Tuberc, 58 ; 479, 1948. 14) Cronk et al.: The absorption and excretion of kanamycin in human beings. J. Lab. Clin. Med., 53; 888, 1959, 15) Robson et al.: Antituberculous drugs. Phanmacol. Rev., 15; 169, 1963. 16) Tisch et al.: Pharmacological studies with kanamycin. Ann. New York Acad. Sc., 76; 44, $1959 . \quad 17)$ Duvall et al.: Site of action of streptomycin upon inner ear sensory cells. Acta otolaryng., 57; 581, 1964. 
18) Voldrich: The kinetics of streptomycin, kanamycin and neomycin in the inner ear., Actaotolaryng., 60;243, 1965. 19) Feingold: Antimicrobial chemotherapeutic agents: the nature of their action and selective toxicity. New England J., 269; 900, 1963. 20) Gale: Mechanisms of antibiotic actions. Pharmacol. Rev., 15; 481, 1963. 21) Dubin et al:: The sequence of some effects of streptomycin in Escherichia coli. Bionchim. Biophys. Acta; 74; 476, 1963. 22) Ashworth et al.: The fine structural localization of adenosine triphosphatase in the small intestine, kidney and liver of the rat. J. Cell. Biol., 17; 1, 1963. 23) Spator et al.: Adenosine triphosphatase activity in the cell membranes of kidney tubulus. J. Biophys. Biochem. Cytol., 4; 765, 1958, 24) McClurkin: A method for the cytochemical demonstration of sodium-activated adenosine triphosphatase. J. Histochem. Cytochem., 12; 654, 1964. 25) Nakai: Histochemistry of the stria vascularis in the inner ear by electron microscopy. Ann. Otol., 74; 326,
1965. 26) Judah et al.: The biochemistry of sodium transport. Biol. Rev., 39; 160, 1964. 27) Whittam: The interdependence of metabolism and active transport. "The cellular functions of membrane transport", Ed. Hoffman, J. F. Prentice. Hall Inc., New Jersey, 1964.2 28) Skou: Enzy. matic basis for active transport of $\mathrm{Na}$ and $\mathrm{K}$ across cell membrane. Physiol. Rev., 45; 596, 1965. 29) Stupp and Rauch: Read at Deutscher HNOKongress, May, 1965.

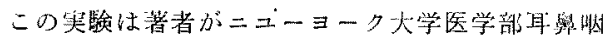
崔科学教室にレジデントとして鼣学中になされた。 J.F. Daly 数授和上び水越治客貝教授の御䩒揵， 御指留に感謝する. R. Gore 氏片よび A.M. Mor-

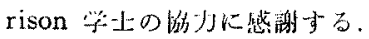

メ，本湔文を作成するにあたり，御之振を践い

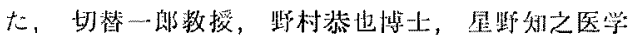

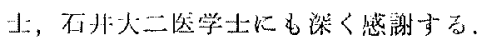

（原稿到媳 $=1$ 利 $41: 4.20$ 日） 